\title{
Toxicological Comparison of Water, Wastewaters and Processed Wastewaters
}

\section{Supporting Information}

\author{
Shengkun Dong, $\wedge \nmid$ Martin A. Page, ${ }^{\S}$ Nedal Massalha, ${ }^{\dagger+}$ Andy Hur, ${ }^{\S}$ Kyu Hur, ${ }^{*}+$ \\ Katherine Bokenkamp, ${ }^{*}+$ Elizabeth D. Wagner, ${ }^{*}+$ Michael J. Plewa ${ }^{*}+*$ \\ $\wedge$ Guangdong Engineering Technology Research Center of Water Security Regulation and Con- \\ trol for Southern China. Key Laboratory of Water Cycle and Water Security in Southern China \\ of Guangdong Higher Education Institute, Sun Yat-sen University, Guangzhou, Guangdong \\ 510275, China \\ $\dagger$ Department of Civil and Environmental Engineering, * Department of Crop Sciences, \\ + Safe Global Water Institute, University of Illinois at Urbana-Champaign, 1101 West Peabody \\ Dr., Urbana, Illinois 61801, United States of America \\ $\S$ US Army Engineer Research and Development Center, \\ 2902 Newmark Dr., Champaign, Illinois 61822, United States of America \\ $<$ The Galilee Society Institute of Applied Research, Shefa-Amr, Israel
}

*Author to whom correspondence should be addressed: Michael J. Plewa; e-mail: mplewa@illi$\underline{\text { nois.edu }}$ 


\section{CHO Cell Cytotoxicity}

The CHO cell cytotoxicity concentration-response curves for the 13 CERL XAD2/8 concentrated water samples are presented in Figures S1 to S13. A summary table of the cytotoxicity and the results of the statistics is presented in Table $\mathrm{S} 1$

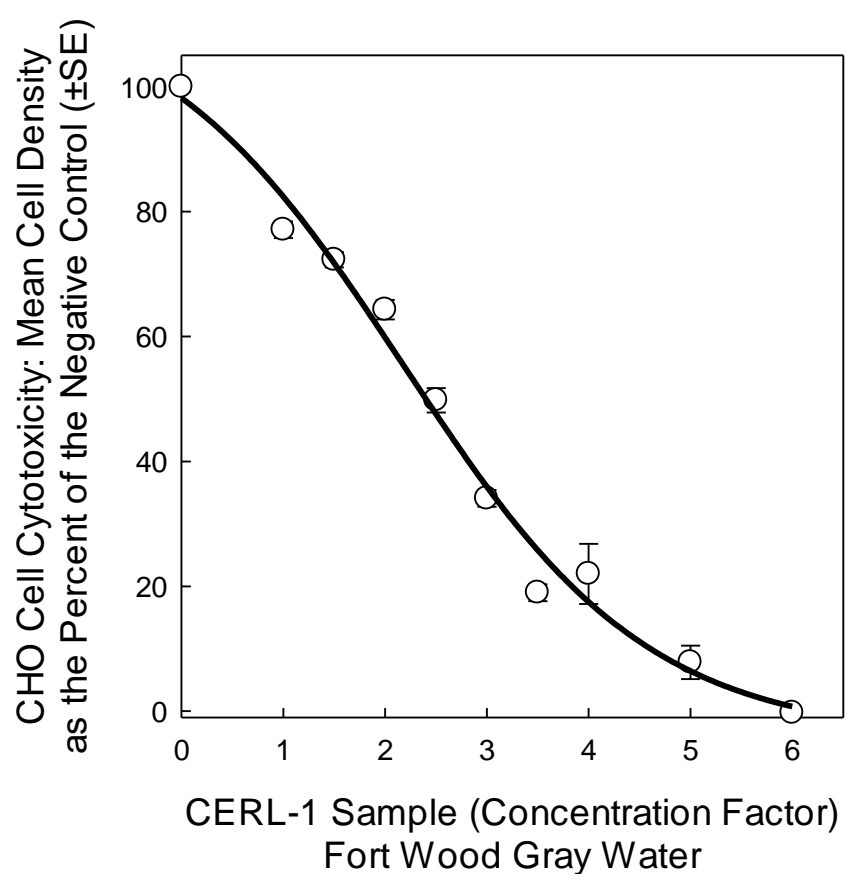

Figure S1. CHO cell cytotoxicity concentration-response curve for water sample CERL-1.

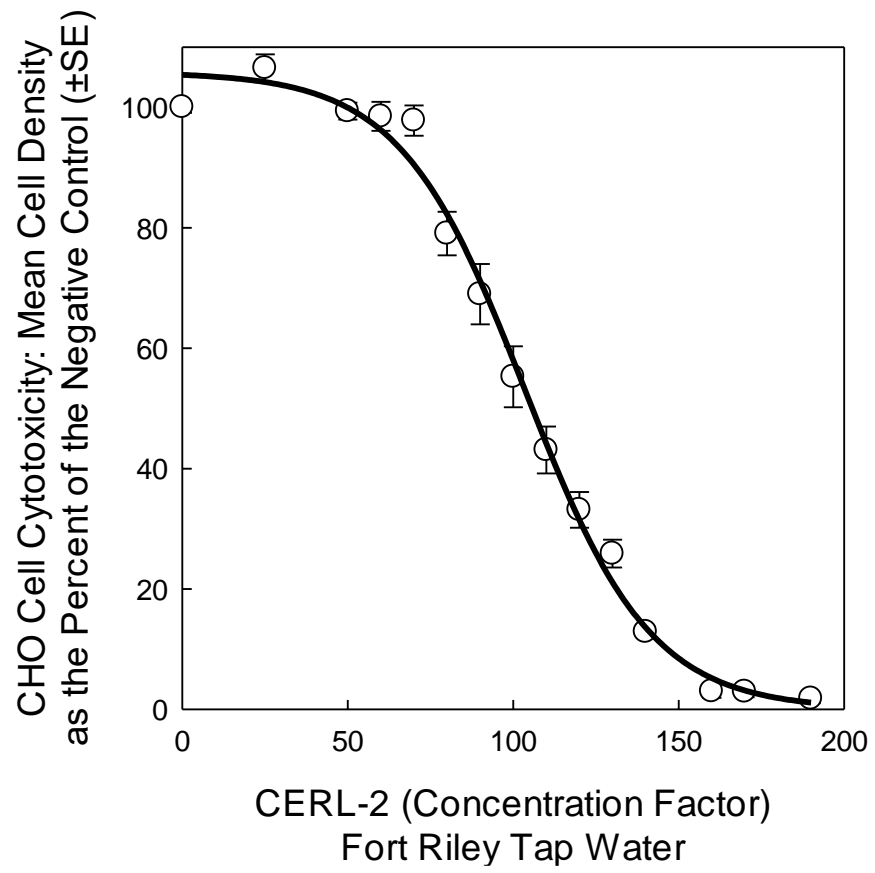

Figure S2. CHO cell cytotoxicity concentration-response curve for water sample CERL-2. 


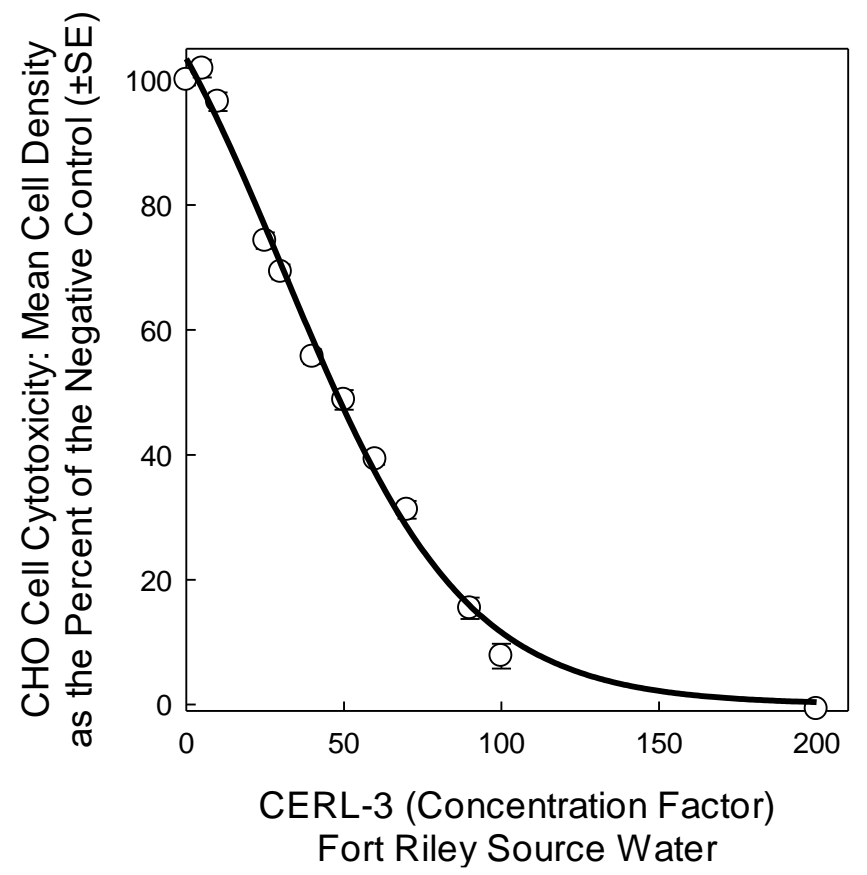

Figure S3. CHO cell cytotoxicity concentration-response curve for water sample CERL-3.

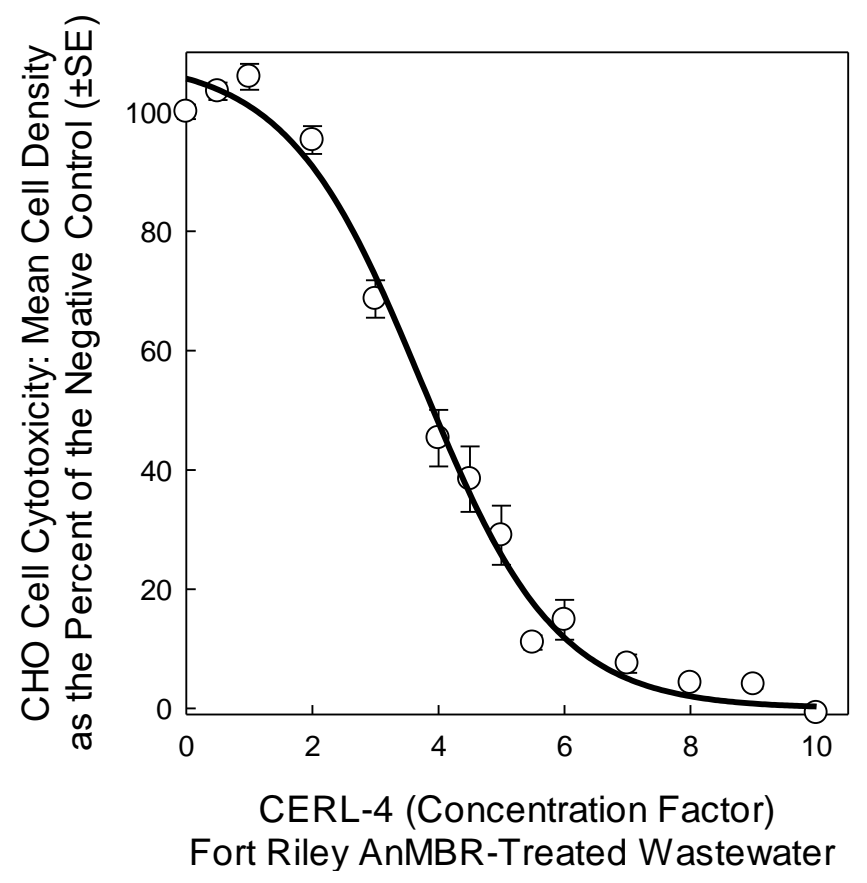

Figure S4. CHO cell cytotoxicity concentration-response curve for water sample CERL-4. 

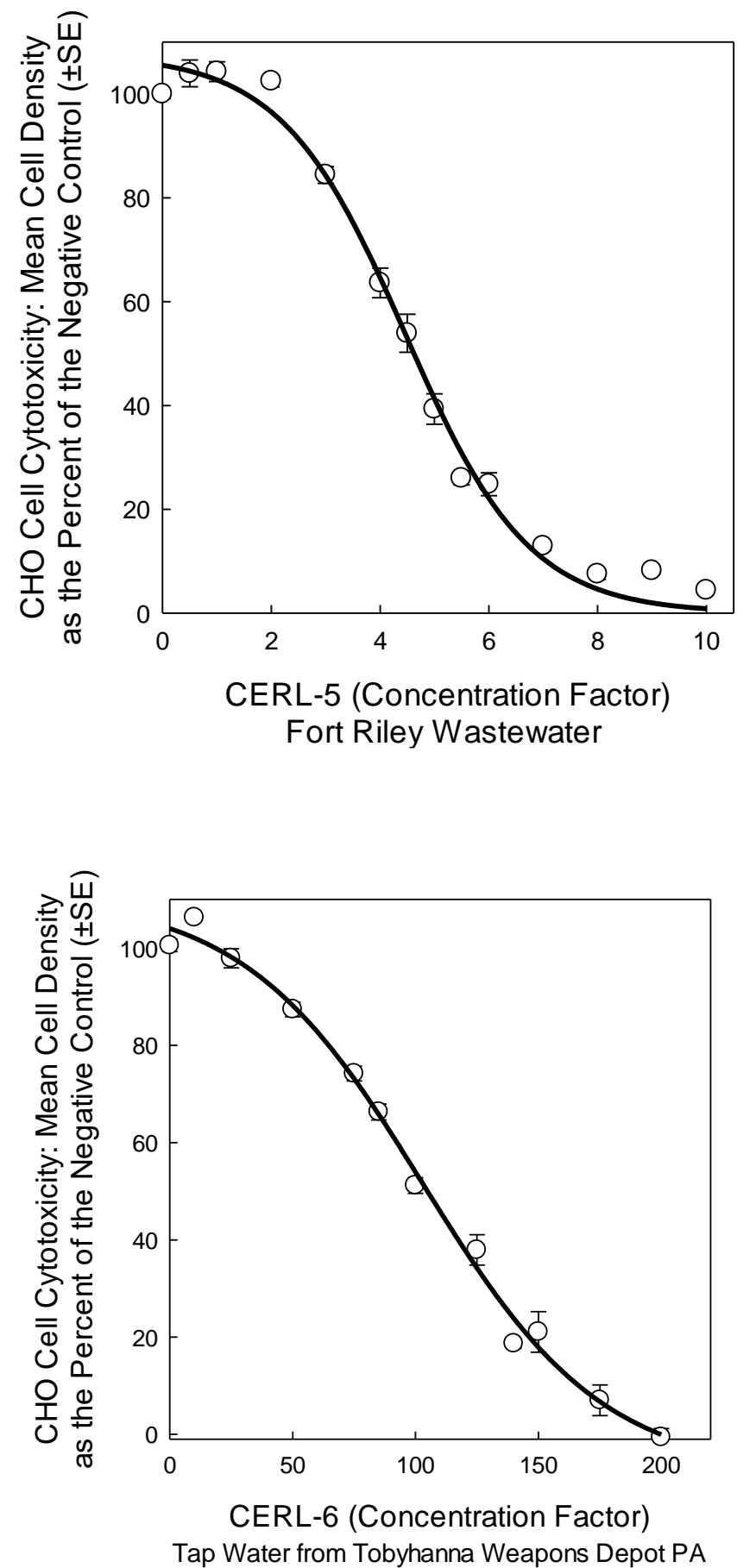

Figure S5. CHO cell cytotoxicity concentration-response curve for water sample CERL-5.
Figure S6. CHO cell cytotoxicity concentration-response curve for water sample CERL-6. 


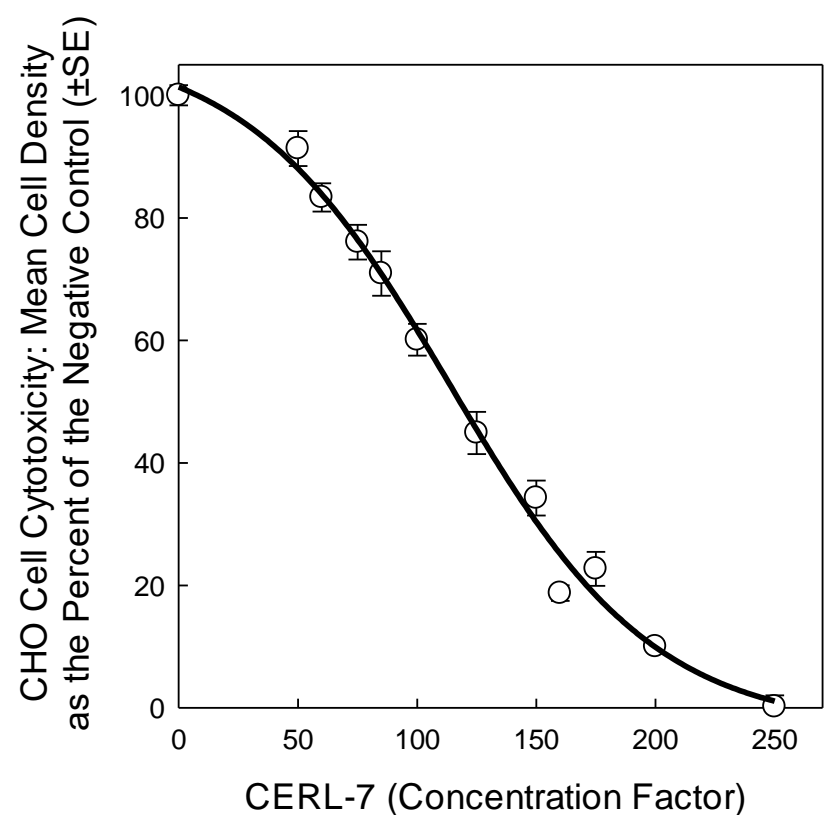

Source Water from Tobyhanna Weapons Depot PA

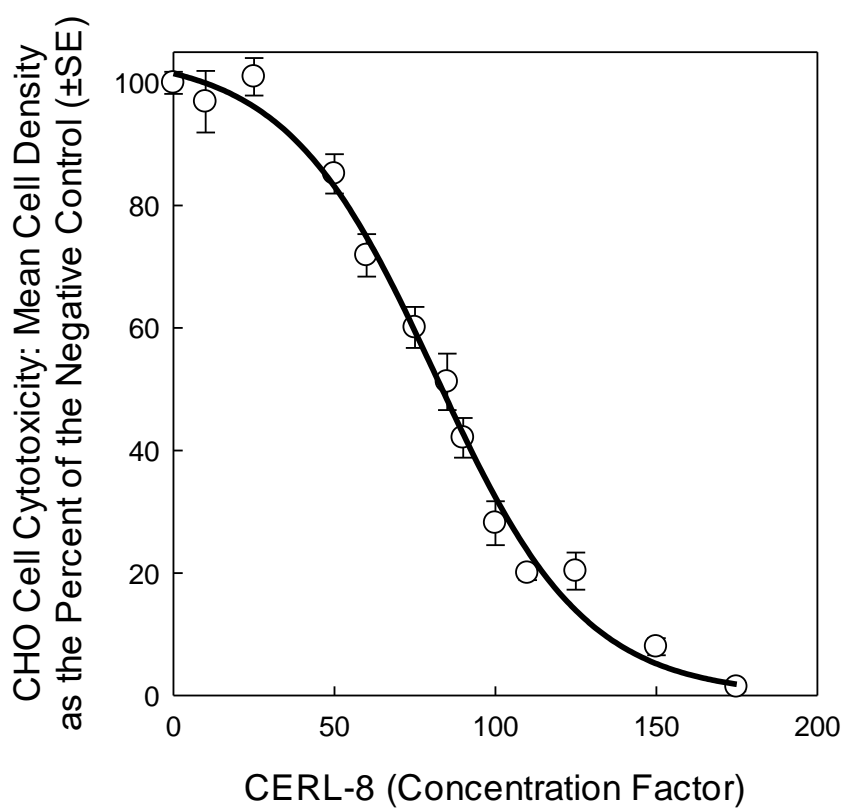

Wastewater Effluent from Tobyhanna Weapons Depot PA
Figure S7. CHO cell cytotoxicity concentration-response curve for water sample CERL-7.
Figure S8. CHO cell cytotoxicity concentration-response curve for water sample CERL-8. 

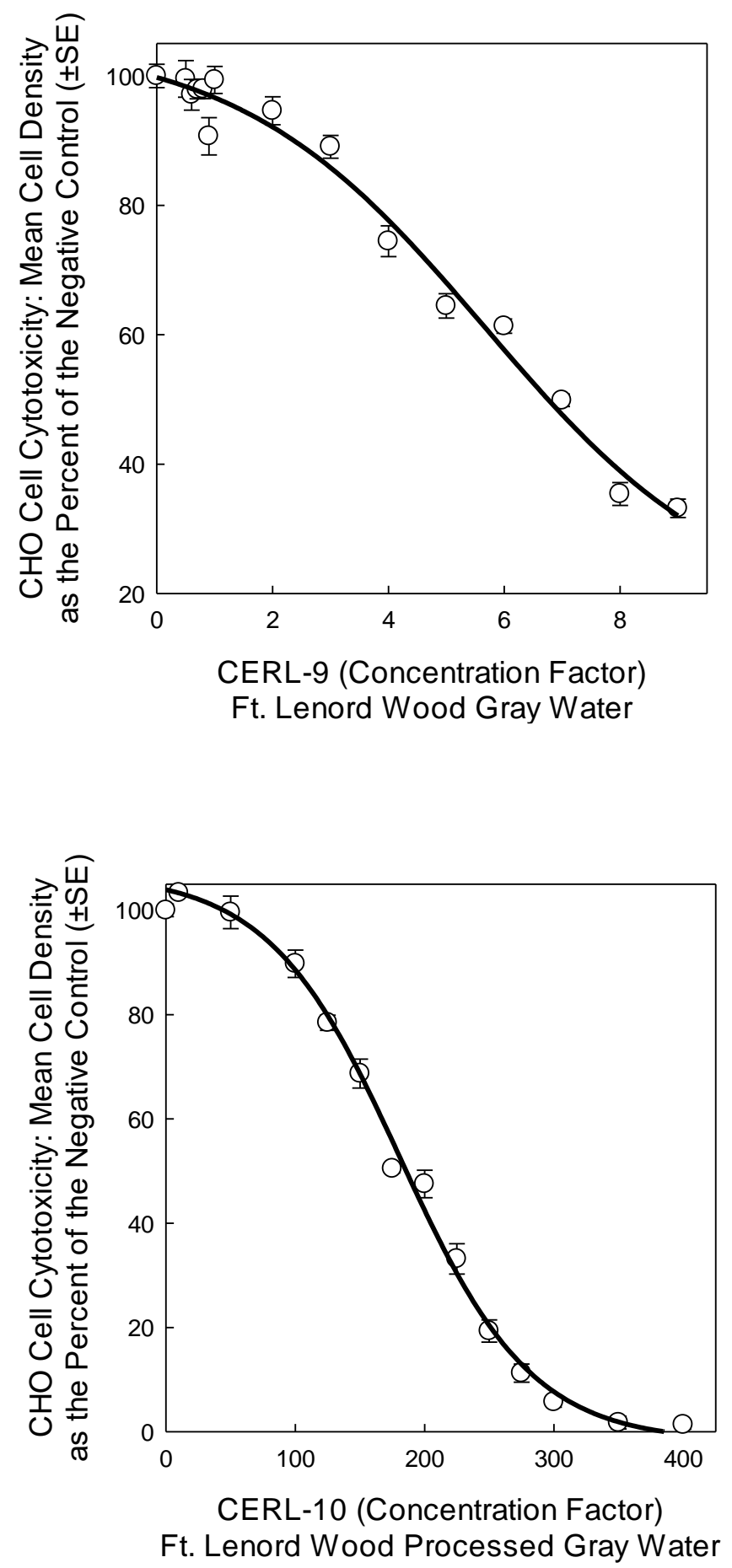

Figure S9. CHO cell cytotoxicity concentration-response curve for water sample CERL-9.
Figure S10. CHO cell cytotoxicity concentration-response curve for water sample CERL-10. 

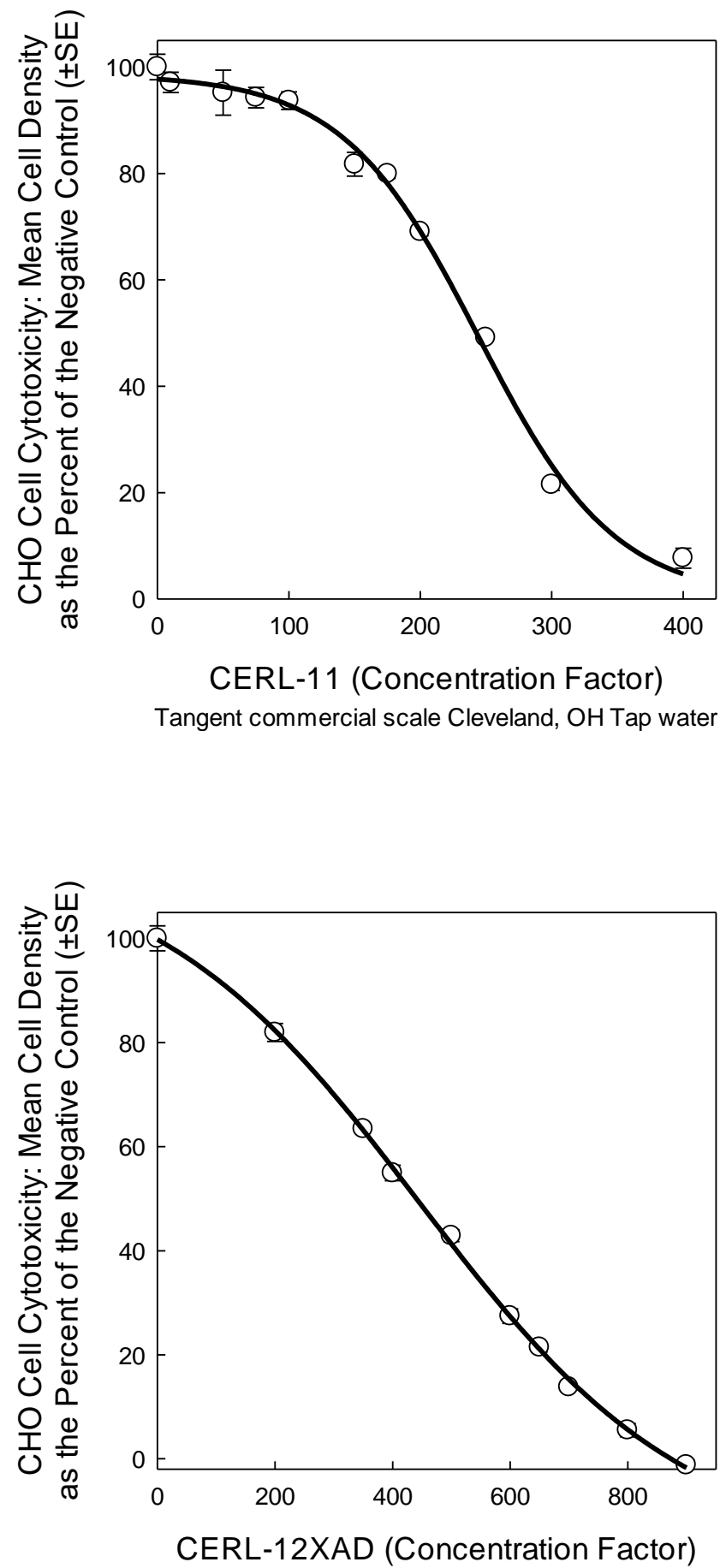

Tangent Tangent commercial scale Cleveland, OH DPR wastewater advanced treatment system product water
Figure S11. CHO cell cytotoxicity concentration-response curve for water sample CERL-11.
Figure S12. CHO cell cytotoxicity concentration-response curve for water sample CERL-12. 


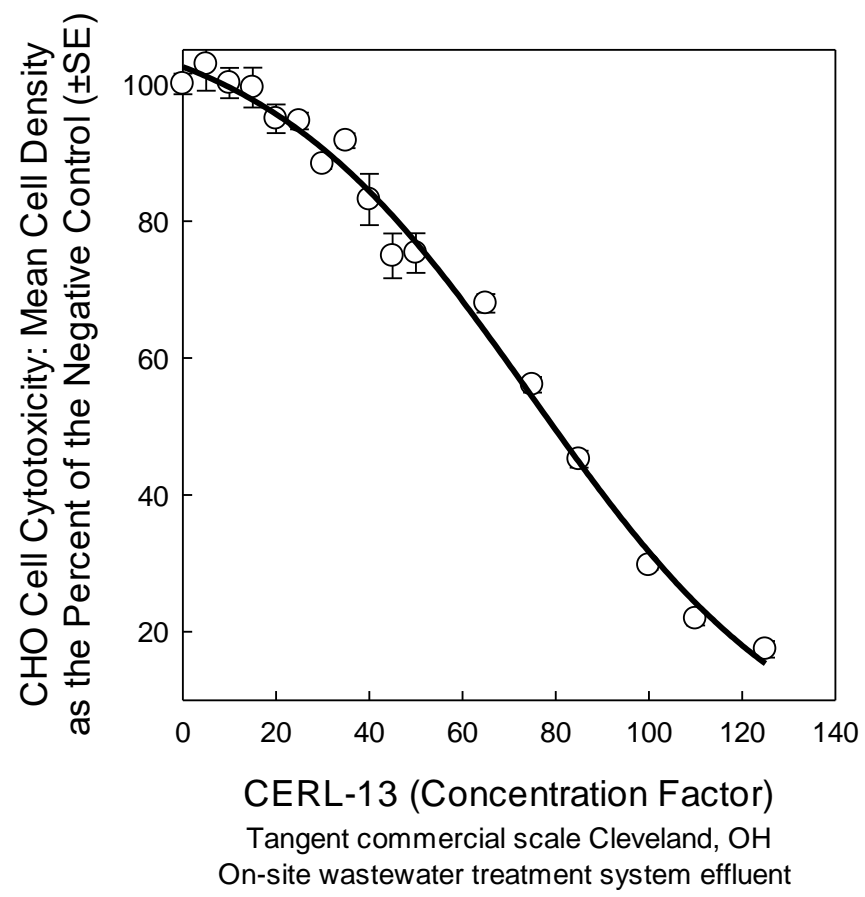

Figure S13. CHO cell cytotoxicity concentration-response curve for water sample CERL-13.

\begin{tabular}{|l|c|c|c|c|}
\hline \multicolumn{5}{|c|}{ Table S1. CHO cell chronic cytotoxicity analyses of CERL XAD2/8 extracted samples } \\
\hline Sample Name & $\begin{array}{c}\text { Lowest Cyto- } \\
\text { toxic } \\
\text { Conc. Factor }\end{array}$ & $\begin{array}{c}\text { LC }_{50} \text { value } \\
(\mathrm{CF} \pm \text { SE })\end{array}$ & $r^{\mathrm{b}}$ & ANOVA Test Statistic $^{\mathrm{d}}$ \\
\hline CERL-1 & 1.00 & $2.42 \pm 0.03$ & 0.99 & $F_{9,118}=239 ; P \leq 0.001$ \\
\hline CERL-2 & 80.0 & $104 \pm 2.57$ & 0.99 & $F_{14,131}=137 ; P \leq 0.001$ \\
\hline CERL-3 & 25.0 & $47.6 \pm 0.82$ & 0.99 & $F_{11,138}=597 ; P \leq 0.001$ \\
\hline CERL-4 & 3.00 & $3.92 \pm 0.16$ & 0.99 & $F_{13,132}=239 ; P \leq 0.001$ \\
\hline CERL-5 & 3.00 & $4.58 \pm 0.09$ & 0.99 & $F_{13,132}=332 ; P \leq 0.001$ \\
\hline CERL-6 & 25.0 & $105 \pm 1.94$ & 0.99 & $F_{10,135}=287 ; P \leq 0.001$ \\
\hline CERL-7 & 50.0 & $117 \pm 3.99$ & 0.99 & $F_{11,139}=166 ; P \leq 0.001$ \\
\hline CERL-8 & 50.0 & $82.5 \pm 2.35$ & 0.99 & $F_{12,138}=147 ; P \leq 0.001$ \\
\hline CERL-9 & 3.00 & $6.75 \pm 0.05$ & 0.98 & $F_{14,134}=108 ; P \leq 0.001$ \\
\hline CERL-10 & 100 & $186 \pm 3.28$ & 0.99 & $F_{13,111}=322 ; P \leq 0.001$ \\
\hline CERL-11 & 150 & $243 \pm 0.78$ & 0.99 & $F_{10,45}=244 ; P \leq 0.001$ \\
\hline CERL-12 & 200 & $443 . \pm 2.95$ & 0.99 & $F_{10,37}=465 ; P \leq 0.001$ \\
\hline CERL-13 & 35.0 & $79.5 \pm 0.45$ & 0.99 & $F_{16,79}=147 ; P \leq 0.001$ \\
\hline
\end{tabular}


${ }^{a}$ Lowest cytotoxic concentration was the lowest concentration factor $(\mathrm{CF})$ of the sample that induced a statistically significant reduction in cell density as compared to the negative control. ${ }^{\mathrm{b}}$ The $\mathrm{LC}_{50}$ value is the concentration of the water sample, determined from a regression analysis of the data, that induced a cell density of $50 \%$ as compared to the concurrent negative controls. The mean and the standard error (SE) were derived from multiple regression analyses using bootstrap statistics ${ }^{c}$ The $r^{2}$ is the coefficient of determination for the regression analysis of the concentrationresponse data upon which the $\mathrm{LC}_{50}$ value was calculated. ${ }^{\mathrm{d}}$ The degrees of freedom for the betweengroups and residual associated with the calculated $F$-test result and the resulting probability value.

\section{CHO Cell Genotoxicity}

The CHO cell genotoxicity concentration-response curves for the 13 CERL XAD2/8 concentrated water samples are presented in Figures S14 to S26. A summary table of the genotoxicity and the results of the statistics is presented in Table $\mathrm{S} 2$.

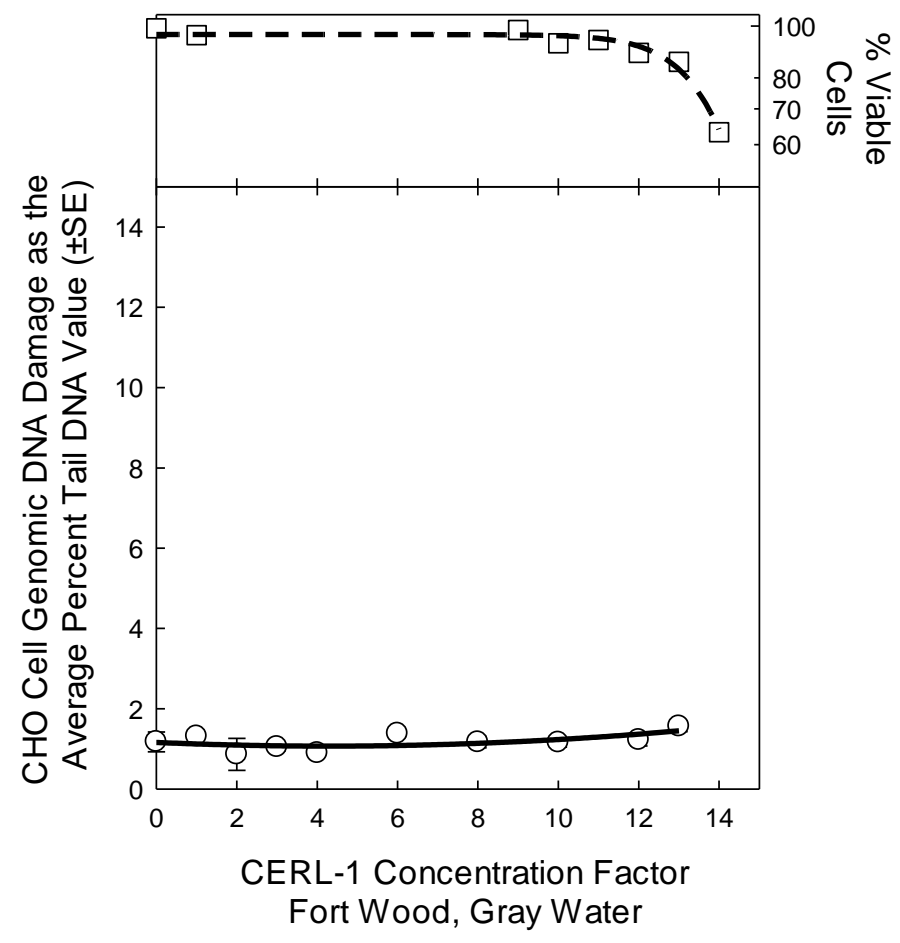

Figure S14. CHO cell genotoxicity concentration-response curve for water sample CERL-1. The top panel illustrates the acute cytotoxicity and the bottom panel illustrates the induction of genomic DNA damage. 

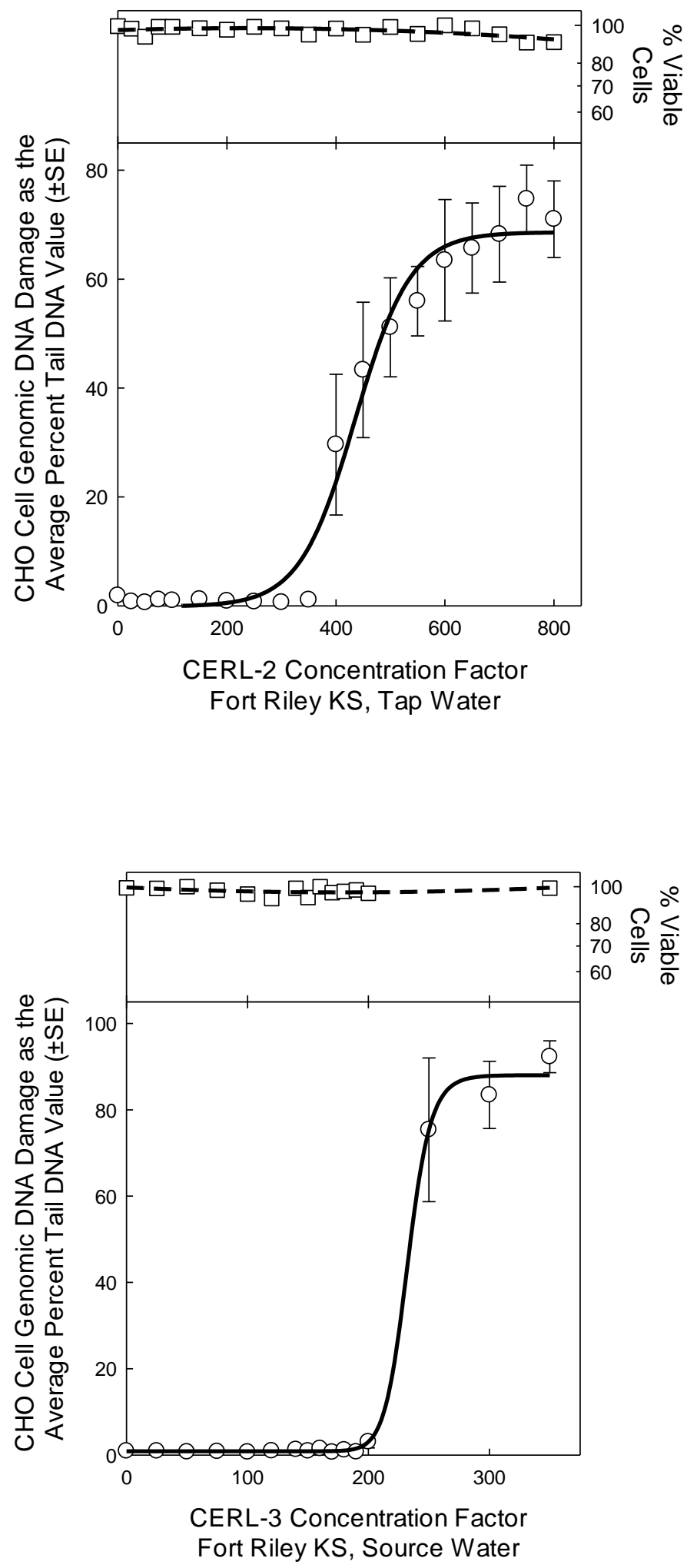

Figure S15. CHO cell genotoxicity concentration-response curve for water sample CERL-2. The top panel illustrates the acute cytotoxicity and the bottom panel illustrates the induction of genomic DNA damage.
Figure S16. CHO cell genotoxicity concentration-response curve for water sample CERL-3. The top panel illustrates the acute cytotoxicity and the bottom panel illustrates the induction of genomic DNA damage. 

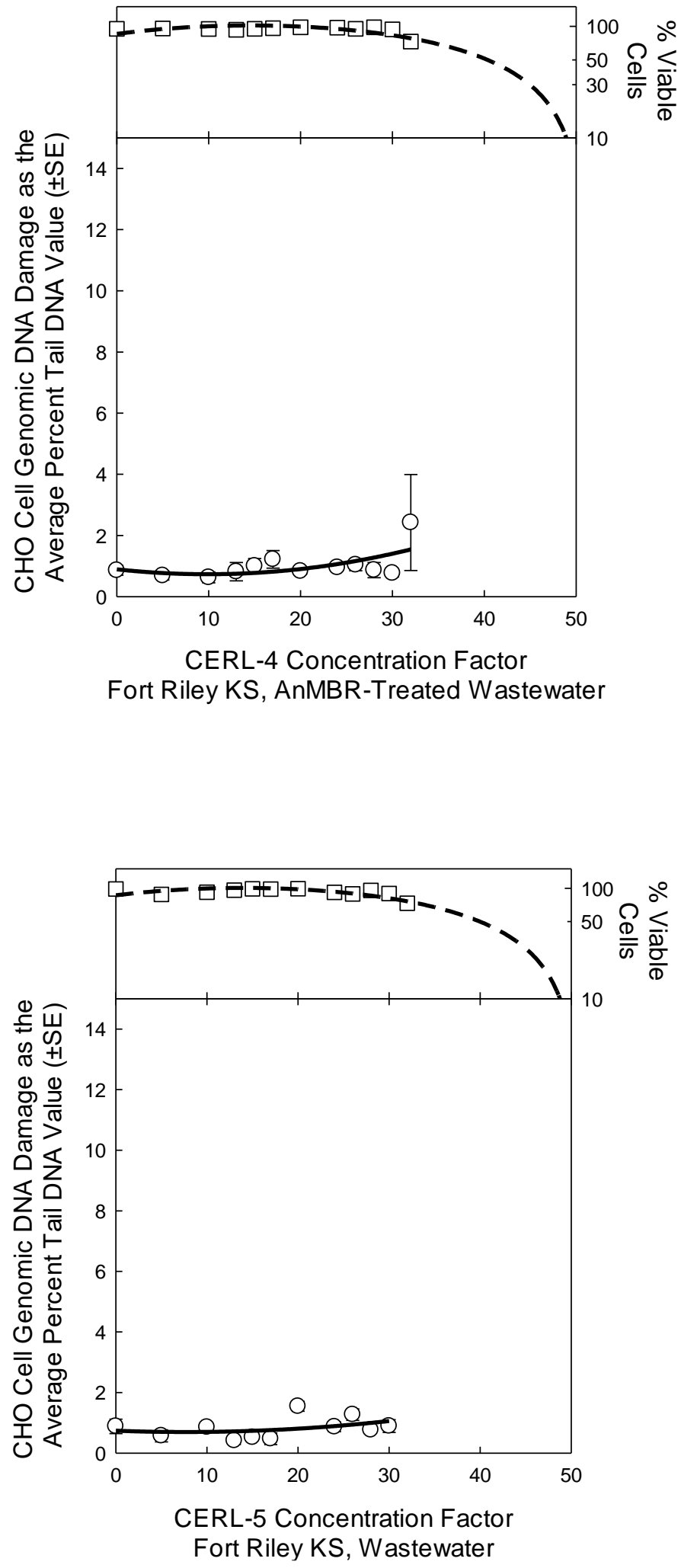

Figure S17. CHO cell genotoxicity concentration-response curve for water sample CERL-4. The top panel illustrates the acute cytotoxicity and the bottom panel illustrates the induction of genomic DNA damage.
Figure S18. CHO cell genotoxicity concentration-response curve for water sample CERL-5. The top panel illustrates the acute cytotoxicity and the bottom panel illustrates the induction of genomic DNA damage. 

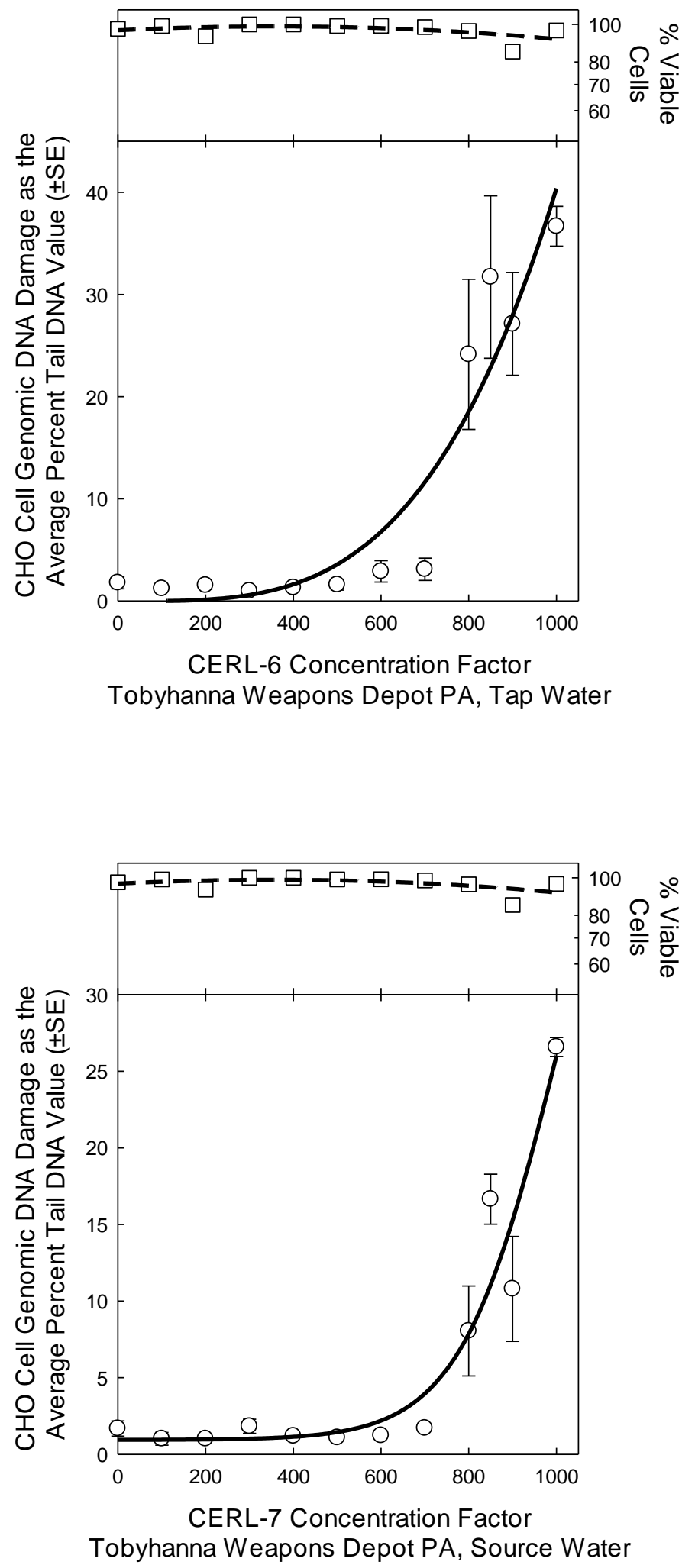

Figure S19. CHO cell genotoxicity concentration-response curve for water sample CERL-6. The top panel illustrates the acute cytotoxicity and the bottom panel illustrates the induction of genomic DNA damage.
Figure S20. CHO cell genotoxicity concentration-response curve for water sample CERL-7. The top panel illustrates the acute cytotoxicity and the bottom panel illustrates the induction of genomic DNA damage. 

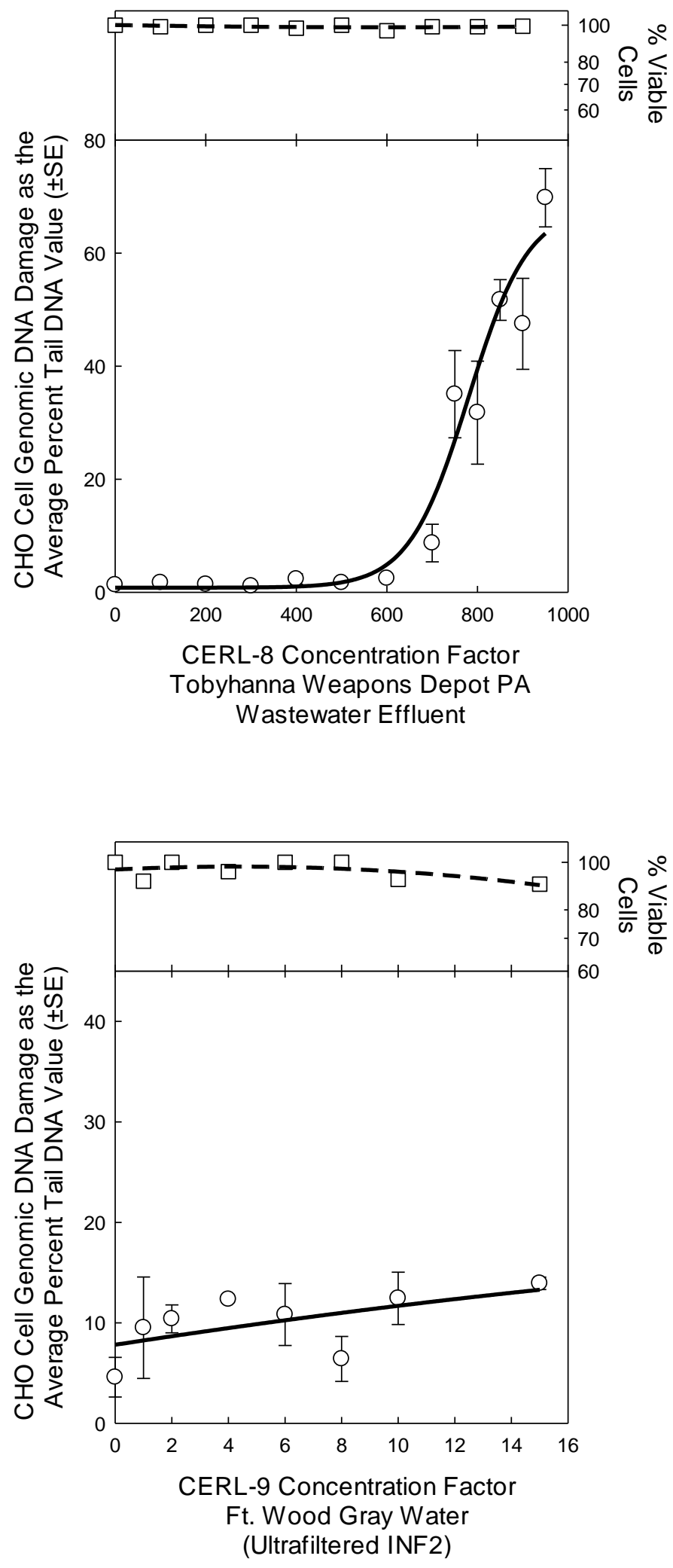

Figure S21. CHO cell genotoxicity concentration-response curve for water sample CERL-8. The top panel illustrates the acute cytotoxicity and the bottom panel illustrates the induction of genomic DNA damage.
Figure S22. CHO cell genotoxicity concentration-response curve for water sample CERL-9. The top panel illustrates the acute cytotoxicity and the bottom panel illustrates the induction of genomic DNA damage. 

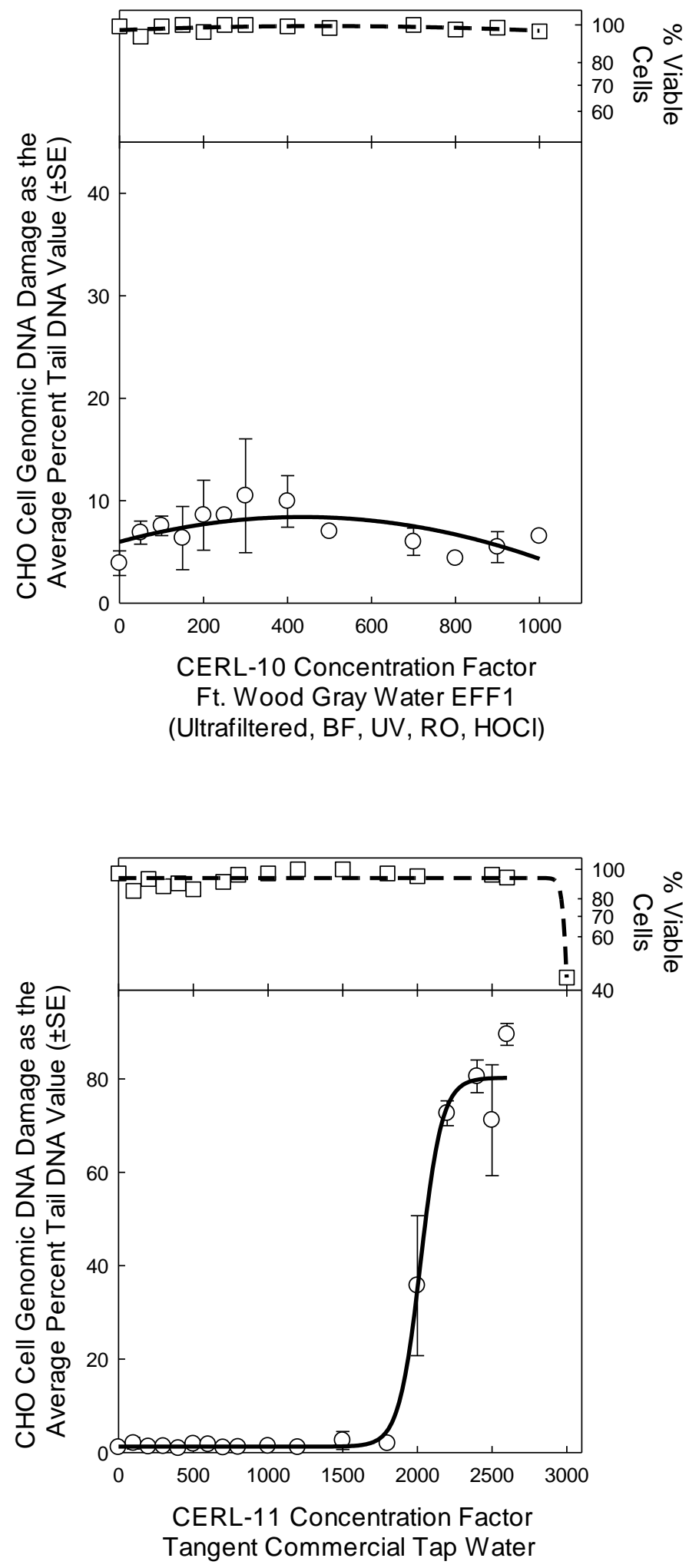

Figure S23. CHO cell genotoxicity concentration-response curve for water sample CERL-10. The top panel illustrates the acute cytotoxicity and the bottom panel illustrates the induction of genomic DNA damage.
Figure S24. CHO cell genotoxicity concentration-response curve for water sample CERL-11. The top panel illustrates the acute cytotoxicity and the bottom panel illustrates the induction of genomic DNA damage. 


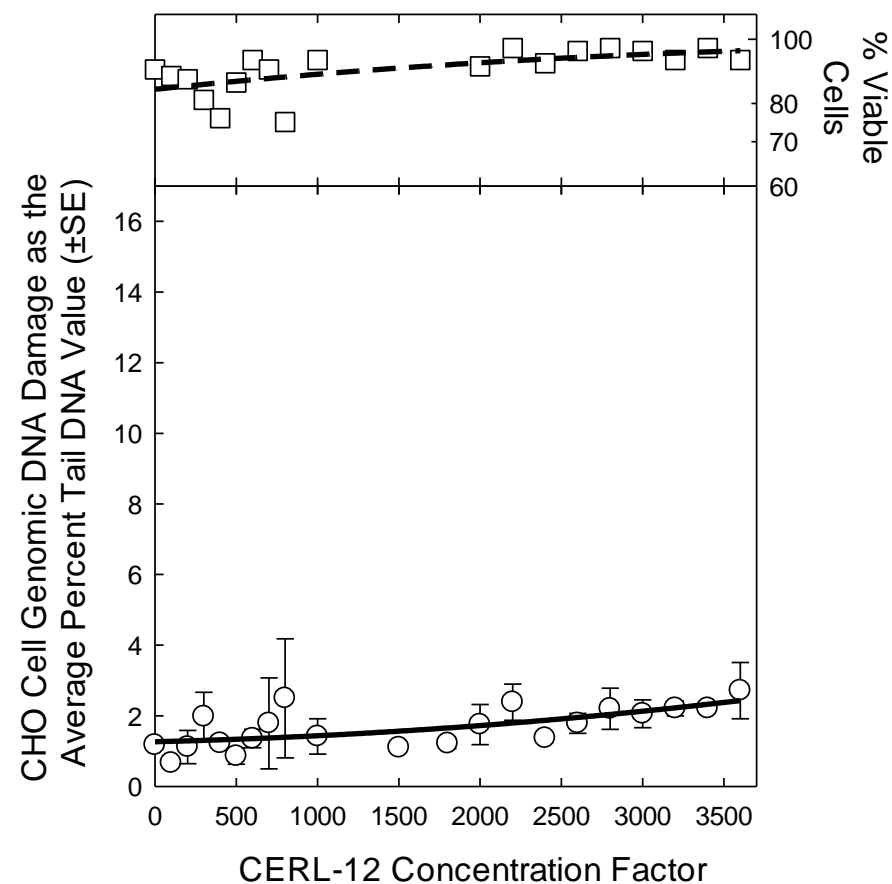

Tangent Commercial Wastewater DPR/Advanced

Treatment System Product Water

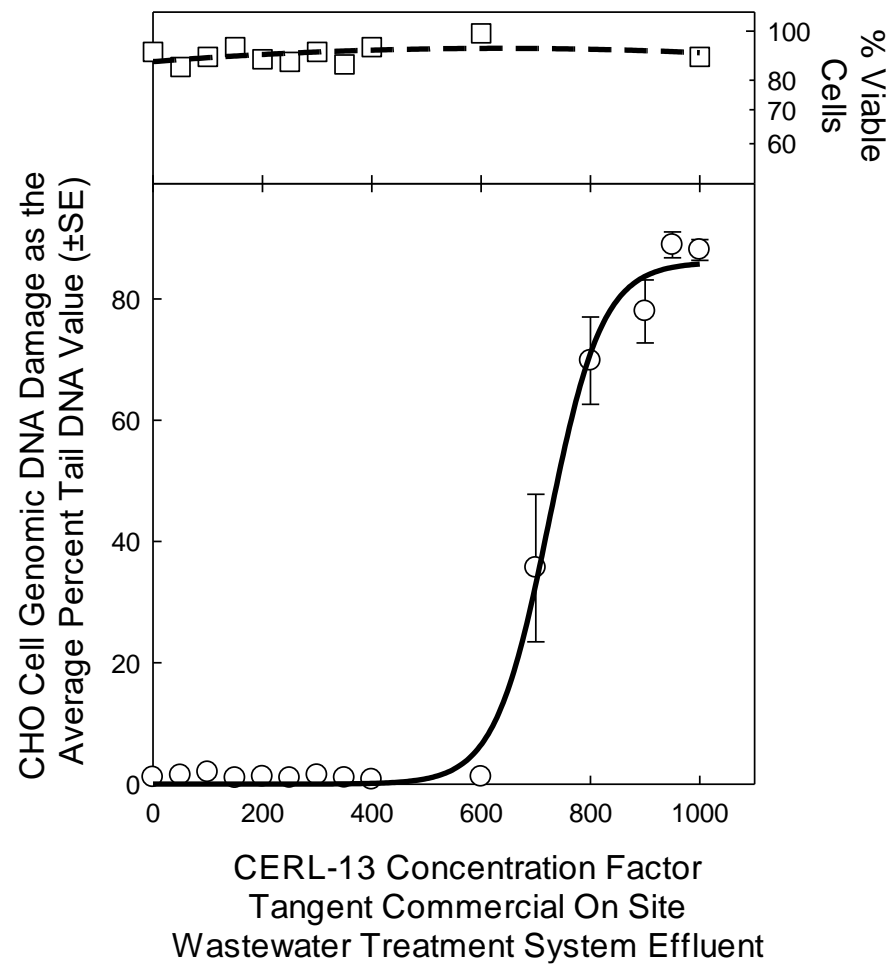

Figure S25. CHO cell genotoxicity concentration-response curve for water sample CERL-12. The top panel illustrates the acute cytotoxicity and the bottom panel illustrates the induction of genomic DNA damage.
Figure S26. CHO cell genotoxicity concentration-response curve for water sample CERL-13. The top panel illustrates the acute cytotoxicity and the bottom panel illustrates the induction of genomic DNA damage. 


\begin{tabular}{|l|c|c|c|c|}
\hline \multicolumn{5}{|c|}{ Table S2. CHO cell acute genotoxicity analyses of CERL-XAD samples } \\
\hline Sample Name & $\begin{array}{c}\text { Lowest Geno- } \\
\text { toxic } \\
\text { Conc. Factor }\end{array}$ & $\begin{array}{c}50 \% \text { Tail } \\
\text { DNA value } \\
(\mathrm{CF} \pm \text { SE) }\end{array}$ & $r^{2 \mathrm{c}}$ & ANOVA Test Statistic $^{\text {d }}$ \\
\hline CERL-1 & NS & NA & NA & $F_{9,29}=1.29 ; P=0.286$ \\
\hline CERL-2 & 450 & $556 \pm 17.9$ & 0.88 & $F_{18,40}=13.2 ; P \leq 0.001$ \\
\hline CERL-3 & 250 & $223 \pm 5.47$ & 0.98 & $F_{16,27}=81.9 ; P \leq 0.001$ \\
\hline CERL-4 & NS & NA & NA & $F_{11,22}=1.40 ; P=0.239$ \\
\hline CERL-5 & NS & NA & NA & $F_{10,24}=2.50 ; P=0.053$ \\
\hline CERL-6 & 800 & $1052 \pm 5.90^{*}$ & 0.89 & $F_{11,24}=9.49 ; P \leq 0.001$ \\
\hline CERL-7 & 850 & $1098 \pm 0.60^{*}$ & 0.92 & $F_{11,18}=12.5 ; P \leq 0.001$ \\
\hline CERL-8 & 750 & $853 \pm 12.1$ & 0.90 & $F_{12,26}=18.2 ; P \leq 0.001$ \\
\hline CERL-9 & NS & NA & NA & $F_{10,7}=1.90 ; P=0.172$ \\
\hline CERL-10 & NS & NA & NA & $F_{12,19}=0.89 ; P=0.572$ \\
\hline CERL-11 & 2000 & $2145 \pm 20.6$ & 0.99 & $F_{17,33}=21.9 ; P \leq 0.001$ \\
\hline CERL-12 & NS & NA & NA & $F_{16,35}=1.39 ; P=0.201$ \\
\hline CERL-13 & 700 & $741 \pm 14.6$ & 0.99 & $F_{14,31}=38.4 ; P \leq 0.001$ \\
\hline
\end{tabular}

${ }^{a}$ The lowest genotoxic concentration was the lowest concentration factor $(\mathrm{CF})$ of the sample in the concentration-response curve that induced a statistically significant amount of genomic DNA damage as compared to the negative control. ${ }^{\mathrm{b}}$ The SCGE 50\% Tail DNA value is the sample concentration factor determined from a regression analysis of the data that was calculated to induce a 50\% SCGE Tail DNA value. The * denotes that the 50\% Tail DNA value was generated by extrapolation. ${ }^{\mathrm{c}}$ The $r^{2}$ is the coefficient of determination for the regression analysis upon which the SCGE \% Tail DNA value was calculated. ${ }^{d}$ The degrees of freedom for the between-groups and residual associated with the calculated $F$-test result and the resulting probability value. NS $=$ not significantly different from the negative control. NA = not applicable.

\section{NAC-Thiol Reactivity Analyses}

The NAC thiol reactivity concentration-response curves for the 13 CERL XAD2/8 concentrated water samples are presented in Figures S27 to S39. A summary table of the thiol reactivity and the results of the statistics is presented in Table S3. 

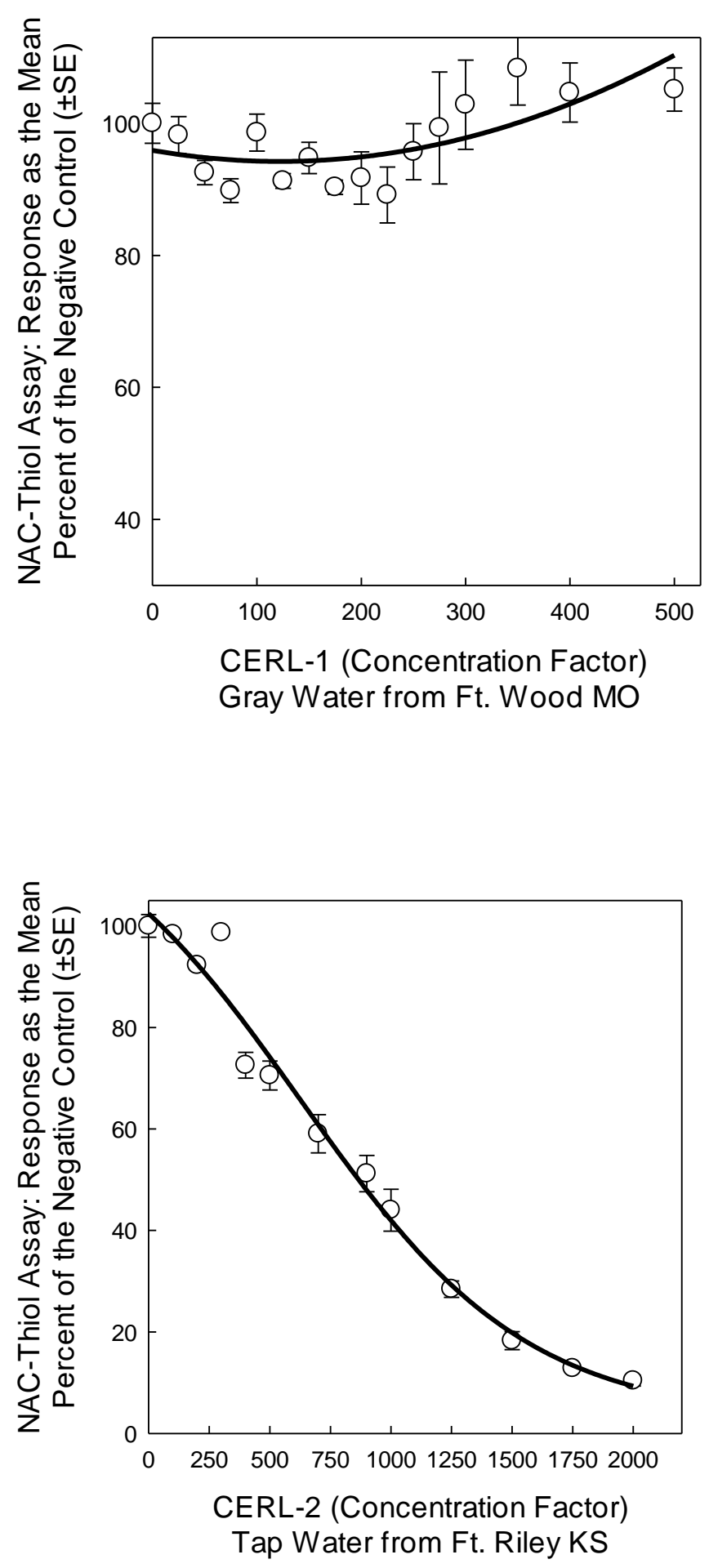

Figure S27. NAC thiol reactivity concentration-response curve for water sample CERL-1.
Figure S28. NAC thiol reactivity concentration-response curve for water sample CERL-2. 

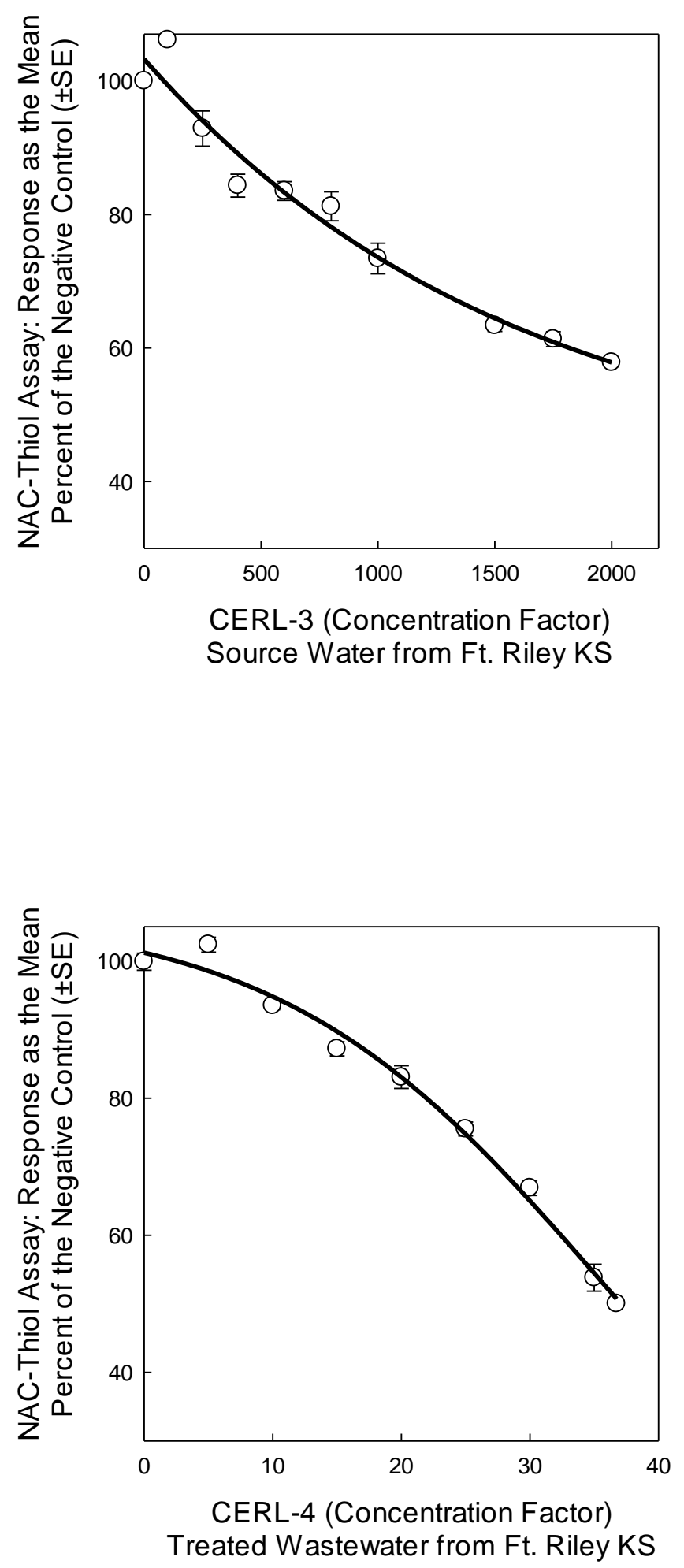

Figure S29. NAC thiol reactivity concentration-response curve for water sample CERL-3.
Figure S30. NAC thiol reactivity concentration-response curve for water sample CERL-4. 

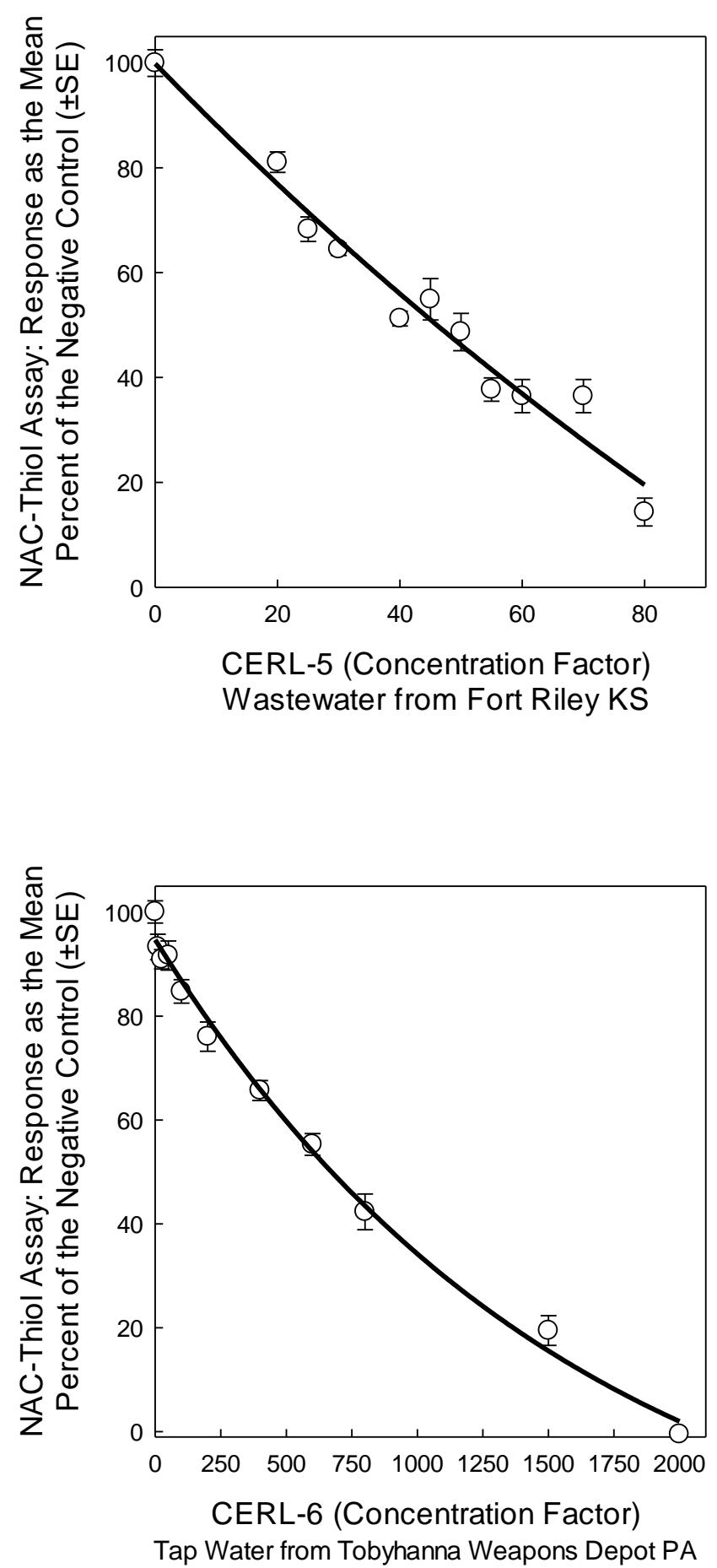

Figure S31. NAC thiol reactivity concentration-response curve for water sample CERL-5.
Figure S32. NAC thiol reactivity concentration-response curve for water sample CERL-6. 

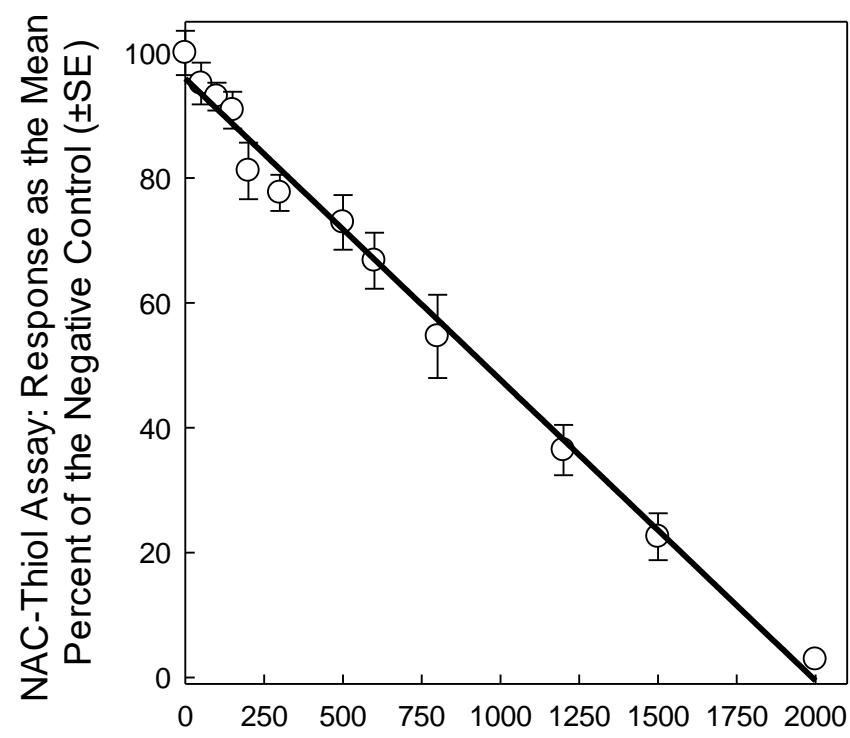

CERL-7 (Concentration Factor)

Source Water from Tobyhanna Weapons Depot PA

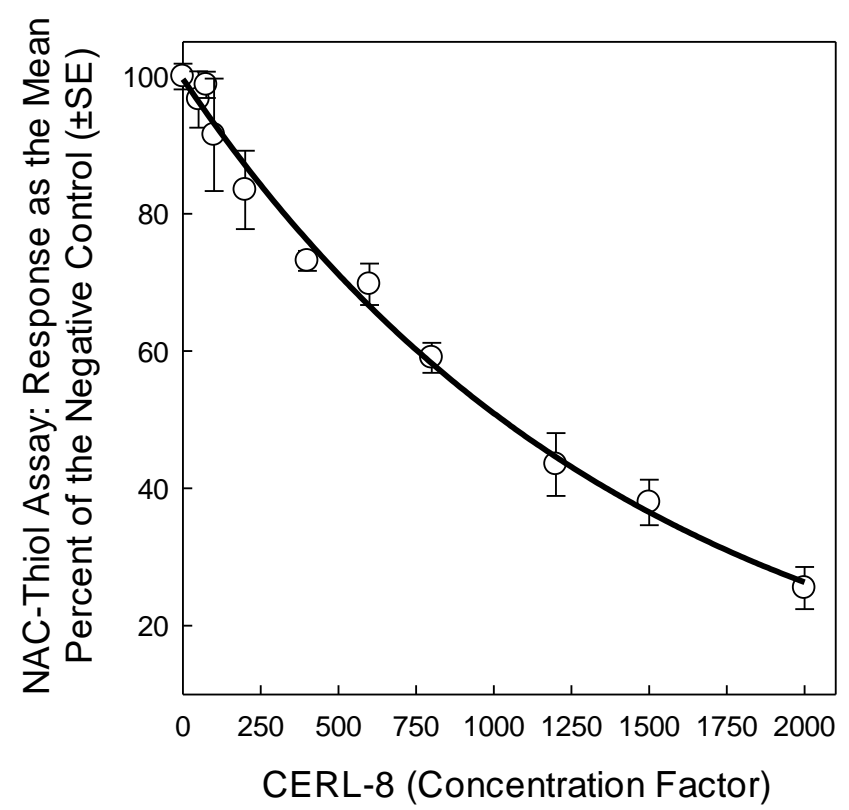

Wastewater Effluent from Tobyhanna Weapons Depot PA
Figure S33. NAC thiol reactivity concentration-response curve for water sample CERL-7.
Figure S34. NAC thiol reactivity concentration-response curve for water sample CERL-8. 

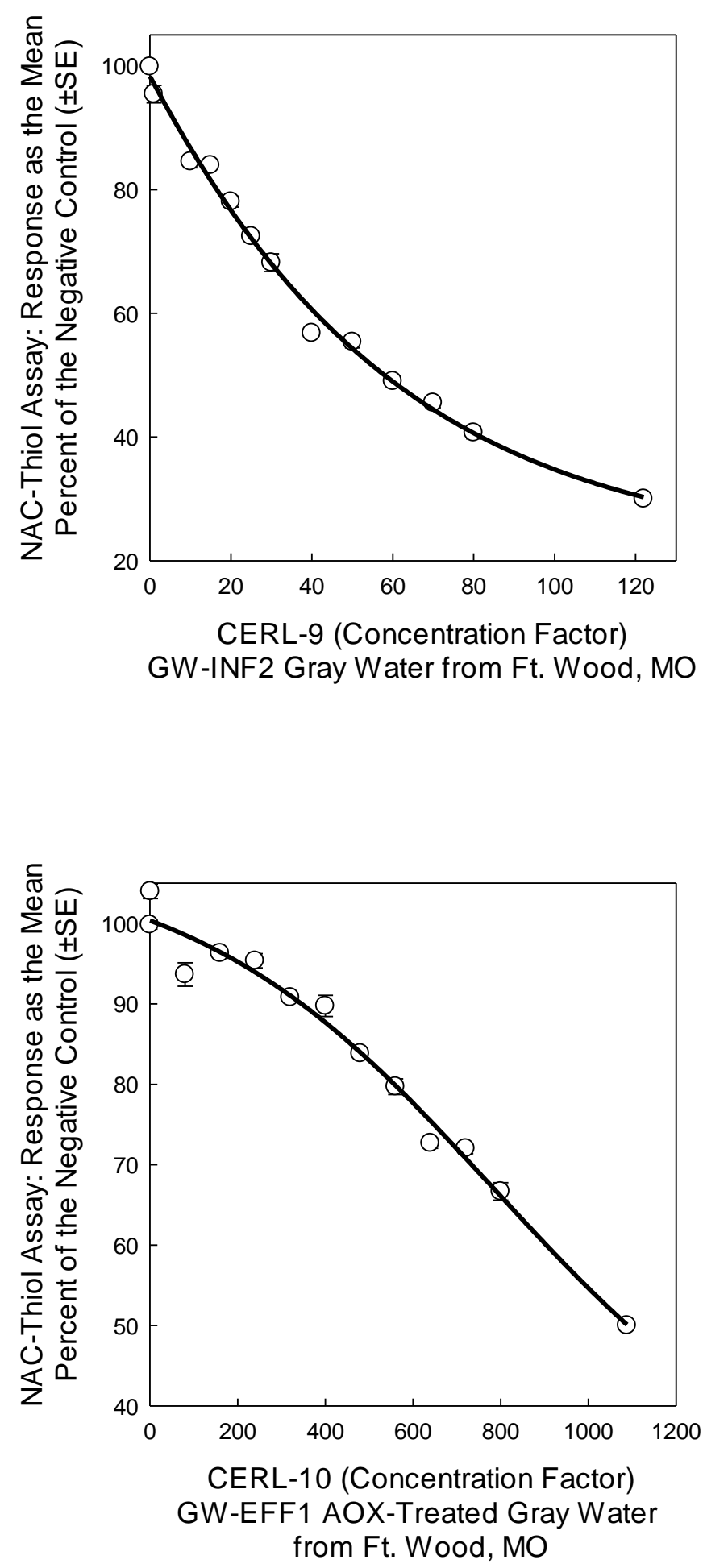

Figure S35. NAC thiol reactivity concentration-response curve for water sample CERL-9.
Figure S36. NAC thiol reactivity concentration-response curve for water sample CERL-10. 

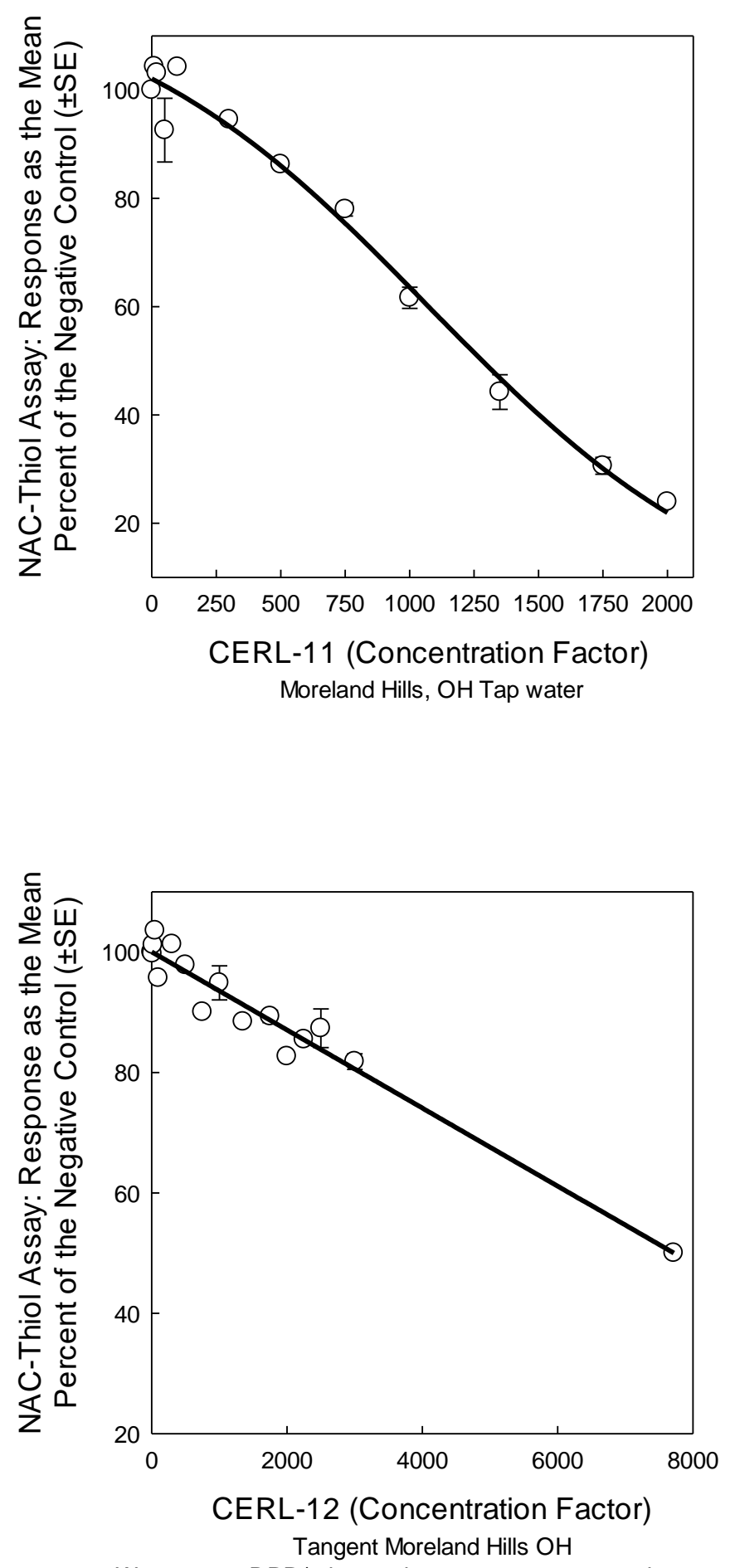

Wastewater DPR/advanced treatment system product water
Figure S37. NAC thiol reactivity concentration-response curve for water sample CERL-11.
Figure S38. NAC thiol reactivity concentration-response curve for water sample CERL-12. 


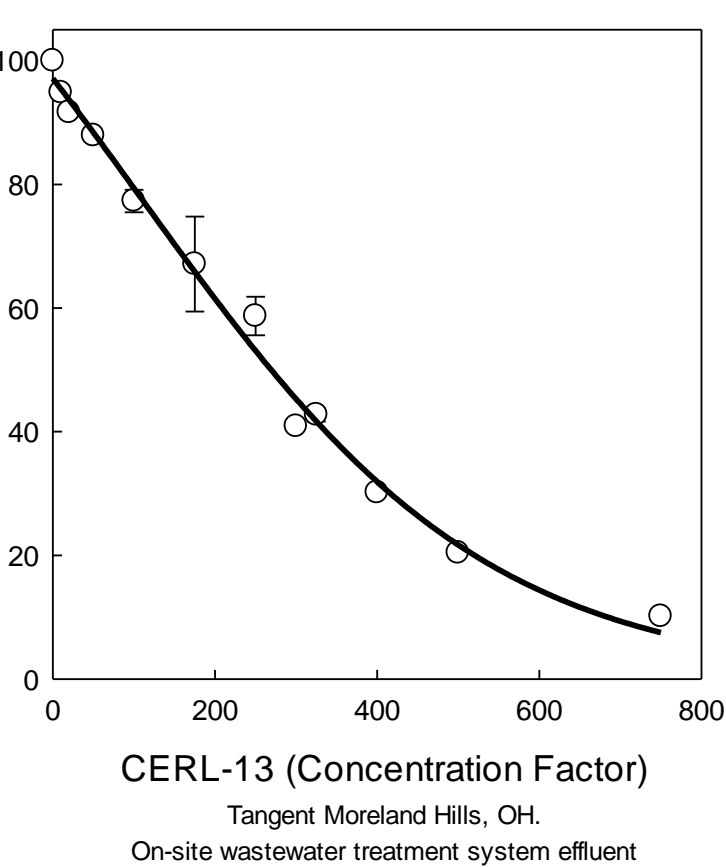

Figure S39. NAC thiol reactivity concentration-response curve for water sample CERL-13.

\begin{tabular}{|l|c|c|c|l|}
\hline \multicolumn{5}{|c|}{ Table S3. NAC thiol reactivity analyses of CERL-XAD samples } \\
\hline Sample Name & $\begin{array}{c}\text { Lowest NAC } \\
\text { response } \\
\text { Conc. Factor }\end{array}$ & $\begin{array}{c}\text { EC }_{50} \text { value } \\
(\mathrm{CF} \pm \text { SE })^{\mathrm{b}}\end{array}$ & $r^{2{ }^{\mathrm{c}}}$ & \multicolumn{1}{|c|}{ ANOVA Test Statistic $^{\mathrm{d}}$} \\
\hline CERL-1 & NS & NA & NA & $F_{15,72}=2.29 ; P=0.234$ \\
\hline CERL-2 & 400 & $857 \pm 33.2$ & 0.98 & $F_{12,40}=116 ; P \leq 0.001$ \\
\hline CERL-3 & 250 & $3011 \pm 64.8^{*}$ & 0.96 & $F_{9,35}=77.2 ; P \leq 0.001$ \\
\hline CERL-4 & 10 & $36.7 \pm 0.17$ & 0.98 & $F_{7,24}=173 ; P \leq 0.001$ \\
\hline CERL-5 & 20 & $46.5 \pm 1.18$ & 0.97 & $F_{10,33}=78.3 ; P \leq 0.001$ \\
\hline CERL-6 & 100 & $660 \pm 32.4$ & 0.99 & $F_{10,39}=86.1 ; P \leq 0.001$ \\
\hline CERL-7 & 200 & $890 \pm 62.3$ & 0.99 & $F_{11,44}=45.4 ; P \leq 0.001$ \\
\hline CERL-8 & 200 & $1028 \pm 54.3$ & 0.99 & $F_{10,43}=40.5 ; P \leq 0.001$ \\
\hline CERL-9 & 1.00 & $57.3 \pm 1.10$ & 0.99 & $F_{11,60}=484 ; P \leq 0.001$ \\
\hline CERL-10 & 80 & $1091 \pm 2.90^{*}$ & 0.96 & $F_{11,60}=179 ; P \leq 0.001$ \\
\hline CERL-11 & 300 & $1241 \pm 16.5$ & 0.98 & $F_{11,84}=748 ; P \leq 0.001$ \\
\hline CERL-12 & 750 & $5957 \pm 12.5^{*}$ & 0.82 & $F_{14,24}=40.1 ; P \leq 0.001$ \\
\hline CERL-13 & 10 & $272 \pm 0.40$ & 0.99 & $F_{11,20}=294 ; P \leq 0.001$ \\
\hline
\end{tabular}

${ }^{a}$ Lowest NAC response concentration was the lowest concentration factor (CF) of the sample that induced a statistically significant reduction in NAC thiol concentration as compared to the negative control. ${ }^{\mathrm{b}}$ The $\mathrm{EC}_{50}$ value is the effective concentration of the sample that induced a reduction in the NAC thiol concentration by $50 \%$ as compared to the concurrent negative control. The * denotes 
that the $\mathrm{EC}_{50}$ value was generated by extrapolation. The mean and the standard error (SE) were derived from multiple regression analyses using bootstrap statistics ${ }^{c}$ The $r^{2}$ is the coefficient of determination for the regression analysis of the concentration-response data upon which the $\mathrm{EC}_{50}$ value was calculated. ${ }^{\mathrm{d}}$ The degrees of freedom for the between-groups and residual associated with the calculated $F$-test result and the resulting probability value.

A Pearson Product Moment Correlation test was calculated to identify relationships amongst total organic carbon (TOC), cytotoxicity (CTI) genotoxicity (GTI) and thiol reactivity (TRI) measurements of the water samples. Table S4 presents the results of the correlation test.

Table S4 Pearson Product Moment Correlation TOC, TRI, CTI, GTI

Cell Contents:

Correlation Coefficient

P Value

Number of Samples

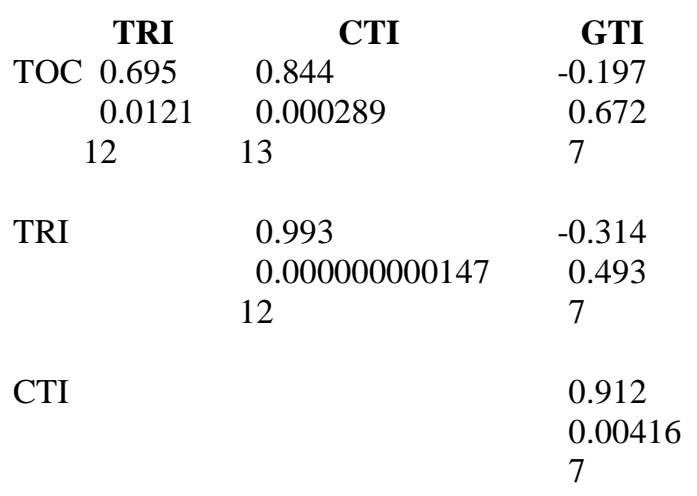

GTI 


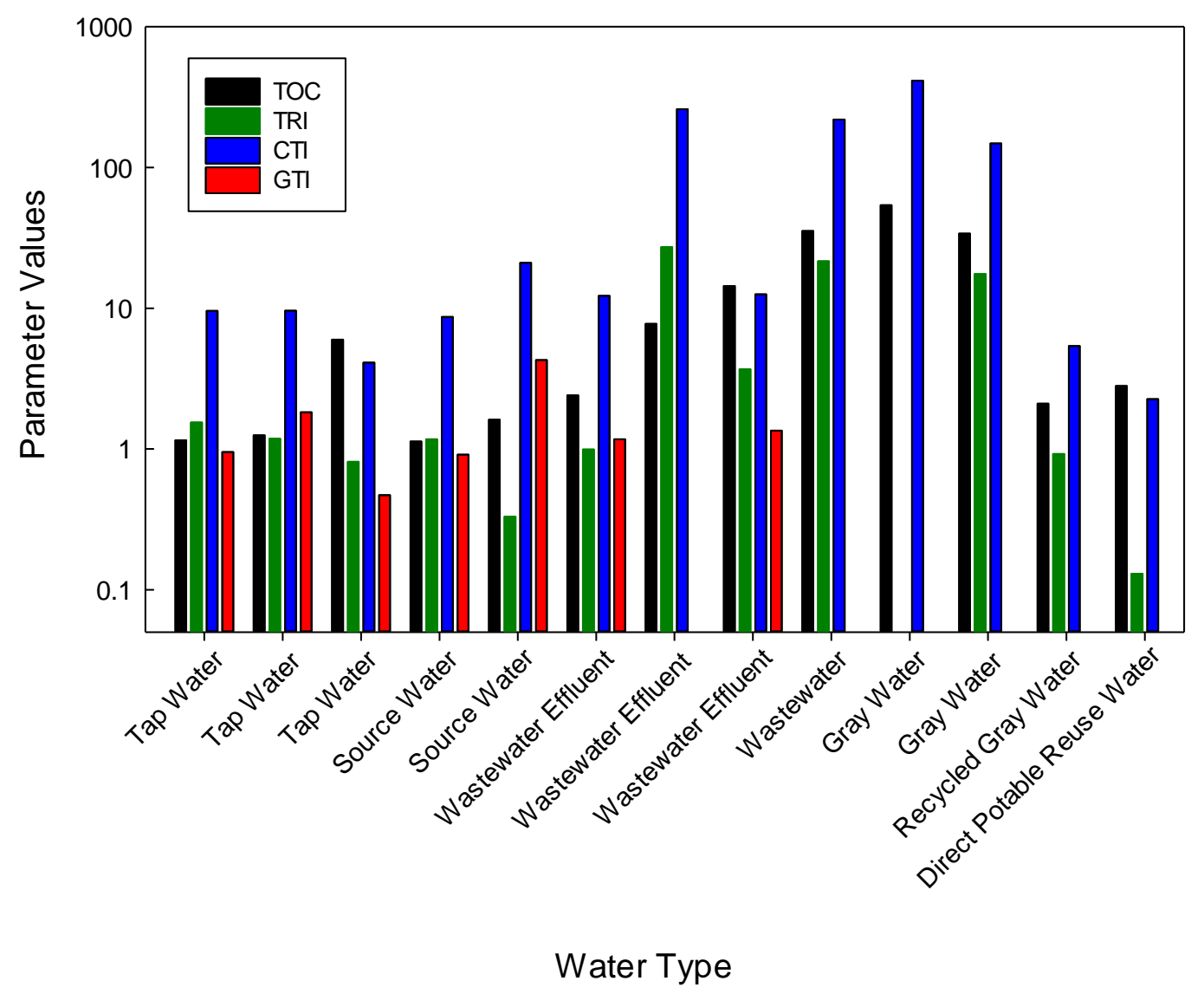

Figure S40. Comparison of the total organic carbon (TOC, mg/L), thiol reactivity index (TRI), cytotoxicity index (CTI), and genotoxicity index (GTI) values generated from 13 concentrated water samples analyzed in this study. 